\title{
Comprehensive transcriptome resource for response to phytohormone-induced signaling in Capsicum annuum L.
}

\author{
Junesung Lee ${ }^{1 \dagger}$, Jae-Young Nam² ${ }^{2 \dagger}$, Hakgi Jang ${ }^{1}$, Nayoung Kim ${ }^{1}$, Yong-Min Kim³ ${ }^{3}$, Won-Hee Kang ${ }^{2 *}$ \\ and Seon-In Yeom ${ }^{1,2^{*}}$ (i)
}

\begin{abstract}
Objectives: Phytohormones are small signaling molecules with crucial roles in plant growth, development, and environmental adaptation to biotic and abiotic stress responses. Despite several previously published molecular studies focused on plant hormones, our understanding of the transcriptome induced by phytohormones remains unclear, especially in major crops. Here, we aimed to provide transcriptome dataset using RNA sequencing for phytohormoneinduced signaling in plant.

Data description: We used high-throughput RNA sequencing profiling to investigate the pepper plant response to treatment with four major phytohormones (salicylic acid, jasmonic acid, ethylene, and abscisic acid). This dataset yielded 78 samples containing three biological replicates per six different time points for each treatment and the control, constituting $187.8 \mathrm{~Gb}$ of transcriptome data (2.4 Gb of each sample). This comprehensive parallel transcriptome data provides valuable information for understanding the relationships and molecular networks that regulate the expression of phytohormone-related genes involved in plant developments and environmental stress adaptation.
\end{abstract}

Keywords: Transcriptome, Phytohormone signaling, Environmental stresses, Capsicum annuum

\section{Objective}

Plants are sessile beings, which are exposed to various attacks from the environment involving biotic/abiotic stress conditions [1,2]. Besides, plants interact with positive effects from plant-associated microbes which induce phytohormones so that strengthen plants to withstand stresses. In response to these physiological processes, different signaling pathways of plant hormones are activated. Infection of plants with diverse pathogens results

\footnotetext{
*Correspondence: wh81kang@gmail.com; sunin78@gnu.ac.kr

†Junesung Lee and Jae-Young Nam contributed equally to this work

${ }^{1}$ Department of Agricultural Plant Science, Division of Applied Life

Science (BK21), Gyeongsang National University, Jinju 52828, Republic

of Korea

${ }^{2}$ Institute of Agriculture \& Life Science, Gyeongsang National University,

Jinju 52828, Republic of Korea

Full list of author information is available at the end of the article
}

in changes in the level of various phytohormones. Three phytohormones-salicylic acid (SA), jasmonic acid (JA) and ethylene (ET), are known to regulating plant defense responses against various pathogens, pests and abiotic stresses. Abscisic acid (ABA) exert opposite defense effect from these hormones, but can also enhance disease resistance $[3,4]$. These phytohormones tend to act interdependently through complex antagonistic or synergistic interactions [5]. These relationships reveal that important networks of phytohormone crosstalk exist to mediate physiological processes such as biotic, abiotic stress tolerance, and plant growth.

Despite several previously reported molecular studies focused on plant hormones, the transcriptome information of phytohormones remains unclear, especially in major crops [6, 7]. Recently a few genes and gene families regulated by phytohormones have been identified

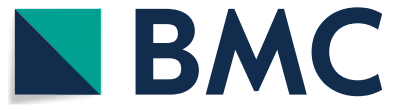

(c) The Author(s) 2020. This article is licensed under a Creative Commons Attribution 4.0 International License, which permits use, sharing, adaptation, distribution and reproduction in any medium or format, as long as you give appropriate credit to the original author(s) and the source, provide a link to the Creative Commons licence, and indicate if changes were made. The images or other third party material in this article are included in the article's Creative Commons licence, unless indicated otherwise in a credit line to the material. If material is not included in the article's Creative Commons licence and your intended use is not permitted by statutory regulation or exceeds the permitted use, you will need to obtain permission directly from the copyright holder. To view a copy of this licence, visit http://creativeco mmons.org/licenses/by/4.0/. The Creative Commons Public Domain Dedication waiver (http://creativecommons.org/publicdomain/ zero/1.0/) applies to the data made available in this article, unless otherwise stated in a credit line to the data. 
in pepper [8-10], but a time-series investigation of the well-regulated transcriptome network has yet to be performed. Accordingly, this study aimed to provide transcriptome dataset using RNA sequencing (RNA-seq) for transcriptome dataset of phytohormone-induced signaling in pepper plant. In this study, we performed transcriptome analysis of pepper treated with four major phytohormones, namely SA, JA, ET, and ABA, at six time points. Total 78 RNA samples were subjected to RNAseq by constructing strand-specific RNA libraries, and $187.8 \mathrm{~Gb}$ of transcriptome data were produced. These transcriptomic profiles will contribute to our understanding of the phytohormone-induced signaling pathways involved in response to environmental stresses and plant development in pepper and other crops.

\section{Data description}

\section{Plant materials and treatment}

Pepper seeds (C. annuum cv. Bukang) were sown on petri dish lined with a wet tissue layer for 2 weeks. After germination, seedlings were transplanted into a 32-cell plug seedling tray and grown at $24 \pm 1{ }^{\circ} \mathrm{C}$ with an alternating 16-h light/8-h dark photoperiod. At the 6-true-leaf stage, pepper plants were sprayed with $5 \mathrm{mM}$ sodium salicylate (SA), $100 \mu \mathrm{M}$ methyl jasmonate (JA), $5 \mathrm{mM}$ ethephone (ET), $100 \mu \mathrm{M}( \pm)$-ABA, or distilled water (mock) [11-14]. Each was treated and incubated in the growth chamber separately to avoid cross-contamination. After treatment, the third or fourth leaf was collected at 0,1 , $3,6,12$, and $24 \mathrm{~h}$ post-inoculation, and frozen with liquid nitrogen immediately prior to storage at $-80{ }^{\circ} \mathrm{C}$. Each treatment time point was performed for three biological replicates, and leaves from four healthy plants were gathered for a replicate.
RNA extraction, library construction, and sequencing Following phytohormone inoculation, total RNA from pepper leaves was extracted using Trizol reagent (Ambion, USA) according to the manufacturer's instructions. To confirm the phytohormone response for each treatment, semi-quantitative RT-PCR was performed using gene primers such as SA (CaPR1), JA (CaPin2), ET (CaACO), and ABA (CaWRKY40) [13-16]. Expression levels were normalized with the CaActin [17] and the mock group was used as a control (Data file 1).

Samples of total RNA $(5 \mu \mathrm{g})$ were used to prepare strand-specific libraries as described previously $[18,19]$. In brief, from each total RNA, the Poly-(A) RNA was captured and fragmented by the size of 300 to $400 \mathrm{bp}$. The RNA fragments were generated second-strand cDNA, and then performed end-repair, dA tailing, adapter ligation and PCR amplification. We generated total $78 \mathrm{cDNA}$ libraries consisting of four treatment groups and a mock control group, for transcriptome profiling. Strandspecific RNA libraries were sequenced using the 151nt paired-end on the HiSeq2500 platform (Illumina, USA) at Macrogen Corporation (Korea) (Table 1).

\section{Quality control and quantification of gene expression}

The adapter filtering and quality trimming was performed on a total of 78 RNA libraries using the Cutadapt and Trimmomatic programs, respectively [20-22]. The read length of each sample was filtered by QC and the read length was 28.87-6.07 Gb (Data file 2). After filtering, the quality of pre-processed reads were checked using FastQC [23] and the output was merged using MultiQC (Data file 3) [24]. Read mapping was carried out with the $C$. annuum 'CM334' reference genome v.1.6 (https://peppergenome.snu.ac.kr) using Hisat2 [25]. Transcriptome quantification was performed using

Table 1 Overview of data files/data sets

\begin{tabular}{|c|c|c|c|}
\hline Label & Name of data file/data set & File types (file extension) & $\begin{array}{l}\text { Data repository and identifier (DOI or accession } \\
\text { number) }\end{array}$ \\
\hline Data set 1 & $\begin{array}{l}\text { Comprehensive transcriptome profiling for response } \\
\text { to phytohormone-induced signaling in Capsicum } \\
\text { annuum L. }\end{array}$ & fastq (.fastq) & $\begin{array}{l}\text { Sequence Read Archive (https://identifiers.org/ncbi/ } \\
\text { insdc.sra:SRP265260) }\end{array}$ \\
\hline Data set 2 & $\begin{array}{l}\text { Comprehensive transcriptome profiling for response } \\
\text { to phytohormone-induced signaling in Capsicum } \\
\text { annuum L. }\end{array}$ & text (.txt) & $\begin{array}{l}\text { Gene Expression Omnibus (https://identifiers.org/ } \\
\text { geo:GSE149037) }\end{array}$ \\
\hline Data file 1 & $\begin{array}{l}\text { Data file 1. Schematic workflow of experimental } \\
\text { design and bioinformatics analysis in this study }\end{array}$ & Adobe acrobat file (.pdf) & $\begin{array}{l}\text { Figshare (https://doi.org/10.6084/m9.figshare.12319 } \\
\text { 337.v6) }\end{array}$ \\
\hline Data file 2 & $\begin{array}{l}\text { Data file } 2 \text {. Statistical summary of RNA-seq with SRA } \\
\text { accession numbers for each treatment }\end{array}$ & MS Excel file (.xIsx) & $\begin{array}{l}\text { Figshare (https://doi.org/10.6084/m9.figshare.12319 } \\
\text { 337.v6) }\end{array}$ \\
\hline Data file 3 & $\begin{array}{l}\text { Data file 3. Quality assessment metrics for RNA-seq } \\
\text { data }\end{array}$ & Adobe acrobat file (.pdf) & $\begin{array}{l}\text { Figshare (https://doi.org/10.6084/m9.figshare.12319 } \\
\text { 337.v6) }\end{array}$ \\
\hline Data file 4 & Data file 4. Normalized FPKM & MS Excel file (.xIsx) & $\begin{array}{l}\text { Figshare (https://doi.org/10.6084/m9.figshare.12319 } \\
\text { 337.v6) }\end{array}$ \\
\hline
\end{tabular}


HTseq-count [26] to calculate the read counts. The clean reads were mapped to the coding DNA sequence with 65.75-70.36\% and the genome with 92.13-96.04\% (Data file 2). Raw read count was normalized to FPKM and visualized with the distribution (Data files 3, 4). The principal component analysis (PCA) with normalized data was used to examine sample variation (Data file 3) [27, 28]. The comparisons between PC1 and PC2 (SA, ET) or PC1 and $\mathrm{PC} 3$ (JA, ABA) indicated that the mock and phytohormone-treated groups were separated clearly.

\section{Limitations}

Raw data was deposited in NCBI, and quality filtering is required before use. The transcriptome data was generated using $C$. annuum cv. Bukang, and read mapping was carried out with $C$. annuum cv. CM334 reference genome.

\section{Abbreviations}

ABA: Abscisic acid; ET: Ethylene; FPKM: Fragments per kilobase of transcripts per million mapped reads; PCA: Principal component analysis; QC: Quality control; RNA-seq: RNA sequencing; RT-PCR: Reverse transcription polymerase chain reaction; SA: Salicylic acid.

\section{Acknowledgements}

We appreciate the support from the KRIBB initiative program.

\section{Authors' contributions}

J-YN collected samples, analyzed data, and wrote the manuscript. JL performed data analysis and wrote the manuscript draft. NK, Y-MK, and HJ collected samples and generated transcriptome data. W-HK and S-IY designed the experiments, organized and wrote the manuscript, and supervised the project. All authors read and approved the final manuscript.

\section{Funding}

This research was supported by the Basic Science Research Program through the National Research Foundation of Korea (NRF) funded by the Korean Government (NRF-2017R1E1A1A01072843, 2015R1A6A1A03031413 and 2019R1C1C1007472). H.J., N.K., and J.L. were supported by a scholarship from the BK21 Program from the Ministry of Education.

\section{Availability of supporting data}

The RNA-seq library of 78 samples are publicly available from the Sequence Read Archive at accession number https://identifiers.org/ncbi/insdc.sra:SRP26 5260 [29]. The quantified transcriptome expression data was deposited in the NCBI Gene Expression Omnibus database with an accession number of https://identifiers.org/geo:GSE149037 [30]. The combined additional files and information generated in this study have been uploaded to figshare, with accession number https://doi.org/10.6084/m9.figshare.12319337.v6 [31].

\section{Ethics approval and consent to participate}

Not applicable.

\section{Consent for publication}

Not applicable.

\section{Competing interests}

The authors declare that they have no competing interests.

\section{Author details}

${ }^{1}$ Department of Agricultural Plant Science, Division of Applied Life Science (BK21), Gyeongsang National University, Jinju 52828, Republic of Korea. ${ }^{2}$ Institute of Agriculture \& Life Science, Gyeongsang National University, Jinju 52828,
Republic of Korea. ${ }^{3}$ Genome Engineering Research Center, Korean Bioinformation Center, Korea Research Institute of Bioscience and Biotechnology, Daejeon 34141, Republic of Korea.

Received: 7 July 2020 Accepted: 9 September 2020

Published online: 18 September 2020

\section{References}

1. Lee HA, Yeom SI. Plant NB-LRR proteins: tightly regulated sensors in a complex manner. Brief. Funct. Genomics. 2015;14(4):233-42.

2. Kang WH, Yeom SI. Genome-wide identification, classification, and expression analysis of the receptor-like protein family in tomato. Plant Pathol. J. 2018;34(5):435-44.

3. Lee SC, Luan S. ABA signal transduction at the crossroad of biotic and abiotic stress responses. Plant Cell Environ. 2012;35(1):53-60.

4. Sewelam N, Kazan K, Schenk PM. Global plant stress signaling: Reactive oxygen species at the cross-road. Front. Plant Sci. 2016;7:187.

5. Shigenaga AM, Argueso CT. No hormone to rule them all: Interactions of plant hormones during the responses of plants to pathogens. Semin. Cell Dev. Biol. 2016:56:174-89.

6. Berens ML, Berry HM, Mine A, Argueso CT, Tsuda K. Evolution of hormone signaling networks in plant defense. Annu. Rev. Phytopathol. 2017;55:401-25.

7. Shigenaga AM, Berens ML, Tsuda K, Argueso CT. Towards engineering of hormonal crosstalk in plant immunity. Curr. Opin. Plant Biol. 2017:38:164-72.

8. Lim CW, Lee SC. Functional roles of the pepper MLO protein gene, CaMLO2, in abscisic acid signaling and drought sensitivity. Plant Mol. Biol. 2014;85(1-2):1-10

9. Jing H, Li C, Ma F, Ma JH, Khan A, Wang X, et al. Genome-wide identification, expression diversication of dehydrin gene family and characterization of $\mathrm{CaDHN} 3$ in pepper (Capsicum annuum L.). PLOS ONE. 2016:11(8):e0161073.

10. Sarde SJ, Bouwmeester K, Venegas Molina J, David A, Boland W, Dicke M. Involvement of sweet pepper CaLOX2 in jasmonate-dependent induced defence against Western flower thrips. J. Integr. Plant Biol. 2019;61(10):1085-98.

11. Kim KJ, Park CJ, An JM, Ham BK, Lee BJ, Paek KH. CaAlaAT1 catalyzes the alanine: 2-oxoglutarate aminotransferase reaction during the resistance response against Tobacco mosaic virus in hot pepper. Planta. 2005;221(6):857-67.

12. Do HM, Lee SC, Jung HW, Sohn KH, Hwang BK. Differential expression and in situ localization of a pepper defensin (CADEF1) gene in response to pathogen infection, abiotic elicitors and environmental stresses in Capsicum annuum. Plant Sci. 2004;166(5):1297-305.

13. Lee SJ, Lee MY, Yi SY, Oh SK, Choi SH, Her NH, et al. PPI1: a novel pathogen-induced basic region-leucine zipper (bZIP) transcription factor from pepper. Mol. Plant Microbe Interact. 2002;15(6):540-8.

14. Kim YC, Kim SY, Paek KH, Choi D, Park JM. Suppression of CaCYP1, a novel cytochrome $\mathrm{P} 450$ gene, compromises the basal pathogen defense response of pepper plants. Biochem. Biophys. Res. Commun. 2006;345(2):638-45.

15. Dang FF, Wang YN, Yu L, Eulgem T, Lai Y, Liu ZQ, et al. CaWRKY40, a WRKY protein of pepper, plays an important role in the regulation of tolerance to heat stress and resistance to Ralstonia solanacearum infection. Plant Cell Environ. 2013;36(4):757-74.

16. Peña-Cortés H, Fisahn J, Willmitzer L. Signals involved in wound-induced proteinase inhibitor II gene expression in tomato and potato plants. Proc. Natl. Acad. Sci. USA. 1995;92(10):4106-13.

17. Yeom SI, Seo E, Oh SK, Kim KW, Choi D. A common plant cell-wall protein HyPRP 1 has dual roles as a positive regulator of cell death and a negative regulator of basal defense against pathogens. Plant J. 2012;69(5):755-68.

18. Zhong S, Joung JG, Zheng Y, Chen YR, Liu B, Shao Y, et al. High-throughput illumina strand-specific RNA sequencing library preparation. Cold Spring Harb. Protoc. 2011;2011(8):940-9.

19. Kang WH, Sim YM, Koo N, Nam JY, Lee J, Kim N, et al. Transcriptome profiling of abiotic responses to heat, cold, salt, and osmotic stress of Capsicum annuum L. Sci. Data. 2020;7(1):1-7. 
20. Ranzani V, Arrigoni A, Rossetti G, Panzeri l, Abrignani S, Bonnal RJ, et al. Next-generation sequencing analysis of long noncoding RNAs in CD4+ T cell differentiation. Methods Mol. Biol. 2017;1514:173-85.

21. Martin M. Cutadapt removes adapter sequences from high-throughput sequencing reads. EMBnet J. 2011;17(1):10-2.

22. Bolger AM, Lohse M, Usadel B. Trimmomatic: a flexible trimmer for Illumina sequence data. Bioinformatics. 2014;30(15):2114-200.

23. Andrews S. FastQC: A Quality Control Tool for High Throughput Sequence Data. Cambridge: Babraham Bioinformatics; 2010

24. Ewels P, Magnusson M, Lundin S, Kaller M. MultiQC: Summarize analysis results for multiple tools and samples in a single report. Bioinformatics. 2016;32(19):3047-8

25. Kim D, Langmead B, Salzberg SL. HISAT: A fast spliced aligner with low memory requirements. Nat. Methods. 2015;12(4):357-60.

26. Anders S, Pyl PT, Huber W. HTSeq-A Python framework to work with high-throughput sequencing data. Bioinformatics. 2015;31(2):166-9.

27. Wold S, Esbensen K, Geladi P. Principal component analysis. Chemom. Intell. Lab. Syst. 1987;2(1-3):37-52

28. Kim MS, Kim S, Jeon J, Kim KT, Lee HA, Lee HY, et al. Global gene expression profiling for fruit organs and pathogen infections in the pepper Capsicum annuum L. Sci. Data. 2018;5:180103.
29. Lee J, Nam JY, Jang H, Kim N, Kim YM, Kang WH, et al. Comprehensive transcriptome profiling for response to phytohormone-induced signaling in Capsicum annuum L. NCBI Sequence Read Archive. 2020. https://ident ifiers.org/ncbi/insdc.sra:SRP265260.

30. Lee J, Nam JY, Jang H, Kim N, Kim YM, Kang WH, et al. Comprehensive transcriptome profiling for response to phytohormone-induced signaling in Capsicum annuum L. Gene Expression Omnibus. 2020. https://identifier s.org/geo:GSE149037.

31. Lee J, Nam JY, Jang H, Kim N, Kim YM, Kang WH, et al. Comprehensive transcriptome resource for response to phytohormone-induced signaling in Capsicum annuum L. figshare. 2020. https://doi.org/10.6084/m9.figsh are.12319337.v6.

\section{Publisher's Note}

Springer Nature remains neutral with regard to jurisdictional claims in published maps and institutional affiliations.
Ready to submit your research? Choose BMC and benefit from:

- fast, convenient online submission

- thorough peer review by experienced researchers in your field

- rapid publication on acceptance

- support for research data, including large and complex data types

- gold Open Access which fosters wider collaboration and increased citations

- maximum visibility for your research: over $100 \mathrm{M}$ website views per year

At BMC, research is always in progress.

Learn more biomedcentral.com/submissions 